\title{
A Comparative Analysis of Financial Distress at PT. Semen Baturaja Tbk. and PT. Semen Indonesia Tbk. from the Period Year of 2012 - 2018
}

\author{
Endang Puji Astuti ${ }^{1}$, Sahroni $^{2}$, Anindya Trisna Wardani ${ }^{3}$ \\ ${ }^{1,2,3}$ Pamulang University, Pamulang, Indonesia \\ \{dosen01682@unpam.ac.id\}
}

\begin{abstract}
The purpose of this research is to find out how big the potential for bankruptcy at PT. Semen Baturaja Tbk and PT. Semen Indonesia Tbk period $2012-2018$ based on the level of financial distress of the company. In this study, the method used is four bankruptcy analysis methods namely the Altman Z-score, Springate, Zmijewski and Grover methods. The data processed in this study are financial data at PT. Semen Baturaja Tbk and PT. Semen Indonesia Tbk for the period of 2012 - 2018 obtained from the websites of the two companies. The results of the study showed the liquidity ratio of PT. Semen Baturaja Tbk is higher and the company's capital is greater than PT. Semen Indonesia Tbk. For solvency ratios at PT. Semen Indonesia Tbk is higher because funding with debt is also greater. The profitability ratio is higher at PT. Semen Indonesia Tbk because PT. Semen Indonesia is better able to maximize the use of assets so that the ability to pay dividends is also better than PT. Semen Baturaja Tbk. Whereas the activity ratio based on the level of sales is higher in the ratio of PT.Semen Baturaja Tbk. and for a higher market ratio at PT. Semen Baturaja Tbk because the company's debt is also large. Despite the fluctuations in PT. Semen Baturaja Tbk and PT. Semen Indonesia Tbk, but the two companies have not been included in the category of potentially bankrupt companies. This is because the company's operational system is still running quite well, can meet short-term debt and make sales. Although included in the category of non-financial distress, the ratio of companies decreased from $2012-2018$.
\end{abstract}

Keywords: Financial Distress, Altman Z-score Method, Springate Method, Zmijewski Method, Grover Method

\section{Introduction}

There was data obtained from the Ministry of Industry of the Republic of Indonesia, over the past 10 years, Indonesia reached the highest point of economic growth in 2011 at $6.2 \%$. At that time, the manufacturing industry was identified to be able to grow until $6.7 \%$. Economic and industrial growth subsequently declined. On average, in 10 years both Indonesia's economic growth was initally recorded at only $5.7 \%$ and industrial growth resulting to a $5 \%$. The low average of industrial growth compared to economic growth has decreased the role of the manufacturing sector towards the Gross Domestic Product (GDP), which was only $22 \%$ in 2014 from the prior a $29 \%$ in 2009 . Exports of manufactured products in the same period apparently were also declining. On the other hand, it was found that the imports continuely were growing even though there was no seriously taking any considerations from the government, because the imports of capital goods and raw materials/components were relatively considered to strengthen 
the capacity of national industries by neglecting the factors of external balance. Meanwhile, a trade balance deficit of the manufacturing industries peaked in 2012 within the US\$ 23 billion, although in 2014 it was reduced to US\$ 6.4 billion along with the falling of imports. The weakening of the manufacturing industry that occurred in every year should be taken seriously. As a study from McKinsey (2012) revealed that to prevent the 'Middle-Income Trap' phenomenon, the role of manufacturing sector in a country on its economy appropriately must reach around $40 \%$. This is because the manufacturing sector is considerably as an activator in order to provide the added values and job creations.

The declining in the manufacturing sector also had an impact on the national cement of manufacturing companies. When the infrastructure is as the main focus of a current government development, it should enable to give the positive impact on the national cement industry. Initially, the incessant cement shipped from China to Indonesia has resulted to the condition of the domestic cement market which was being oversupplied. Certainly, this condition should not be allowed continuously because it would harm the local cement products and could affect to the threat of the bankruptcy. Considering the problems that found in the national cement industry, which could probably give an impact on the threat of the bankruptcy, the researcher will discuss the financial condition of two companies that they both are categorized as quite large cement companies in Indonesia, namely; PT. Semen Baturaja PT Semen Baturaja (Persero) Tbk and PT. Semen Indonesia (Persero) Tbk. PT Semen Baturaja (Persero) Tbk which have shown a record of profit in 2018 of Rp76.07 billion, or decreased into $48.12 \%$.

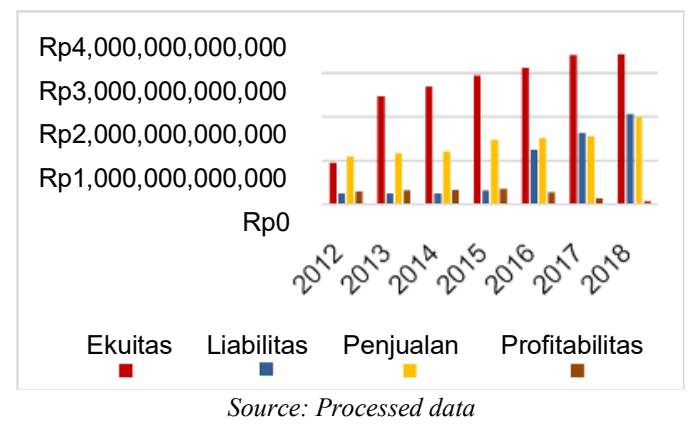

Fig1. The Financial Condition Chart of PT. Semen Baturaja Tbk. during the period of year 2012 2018

Furthermore, $P T$. Semen Indonesia, this cement industry solely has the advantage from the infrastructure integration with $P T$. Solusi Bangun Indonesia (SBI) which aims to strengthen the networks in sales and distributions. This currently draws the declining of company's cement sales much deeper than the weakening of national cement sales. If the condition of the national cement industry continuesly declines even worse, the cement company is potentially going to be bankrupt. 


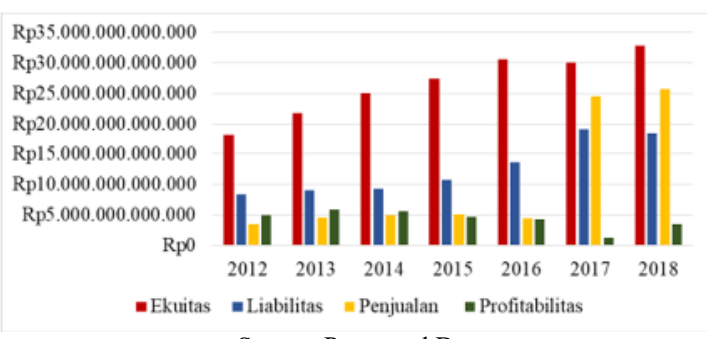

Source: Processed Data

Fig.2. The Financial Condition Chart of PT. Semen Indonesia Tbk during the period $2012-2018$

In accordance with the research questions, the objectives of this research are as follows:

a) Investigating the financial distress analyses using the Altman Z - Score, Springate, Zmijewski and Grover method s of PT. Semen Baturaja Tbk and PT. Semen Indonesia Tbk during the year period of $2012-2018$.

b) Describing the results of the comparison using the Altman $Z$ - Score, Springate, Zmijewski and Grover method s in measuring financial distress of PT. Semen Baturaja Tbk and PT. Semen Indonesia Tbk during the year period of 2012 - 2018.

There have several studies concluded the results of the different methods of bankruptcy analysis. Based on the research from Purnajaya (2014), there was a difference between the method of Z - Score Altman, Springate, and Zmijewski in bankruptcy prediction of manufacturing companies in the cosmetics sector. According to Purnajaya (2014), among the three methods, the Altman method showed as a method that has a mean difference, while Springate and Zmijewski had the same average rate in bankruptcy prediction. This percpective's author was contradictory to Ngatijah (2016) who said that the Grover prediction model was the best bankruptcy prediction model compared to the Altman, Springate and Zmijewski models with an accuracy rate of $68 \%$. The Springate Model is appropriate to be applied to mining companies and has an accuracy rate of $84.21 \%$ (Priambodo, 2017). The different findings in these researches resulting from the accuracy of the analysing method of bankruptcy prediction attracted the researchers's interest to find out how much the bankruptcy potential and financial distress in the two big cement companies in Indonesia by using four (4) methods of analyzing bankruptcy. In line with the existing phenomenon, this research attempts to address the two following questions: How are the financial distress analyses using the Altman Z - Score, Springate, Zmijewski and Grover method s of PT. Semen Baturaja Tbk and PT.

\section{Literature Review}

\subsection{Bankruptcy}

In Karina (2014: 19), "bankruptcy defines as a condition where the company no longer able to repay their obligations". Additionally, Munawir (2010) considered, bankruptcy firstly gets started by financial distress, which is a situation where the company is unable to pay off the financial obligations when there is a due date as it might affect the company to go bankrupt. Bankruptcy can also be said as a failure of the company in carrying out the overall business 
operations, at least to cover debts within their own assets. According to Hanafi and Abdul Halim (2012: 259), the information of bankruptcy can provide benefits for several parties, as follows:

\section{a) The Lender (banks)}

The bankruptcy information can respect to decisions making regard to whom the loans are given to, and even simply benefited for monitoring policies on the existing loans.

\section{b) Investors}

The investors who buy shares or obligations which are issued by a company will certainly need to see the possibility of whether there will be bankruptcy or not in the company that sells the securities.

\section{c) The Government}

In some business sectors, the government institutions have the responsibility to oversee the running of the business performances (e.g. the banking sector). The government also has business entities (BUMN) which need to always be monitored in controlling the finance. Moreover, government institutions automatically have an authority in noticing the signs or cautions of bankruptcy prediction early enough to be useful to actions -Actions that neecessarily for doing predictive accuracy earlier.

\section{d) Accountants}

Accountants orderly have in an attempt concerning on the information of business continuity because accountants will assess the skills of going concern in a company.

\section{e) Management}

Bankcrupty means the emergence of costs in signalling of such a situation for bankruptcy which the costs are quite large. If the management can detect this bankruptcy earlier, then austerity measures can be carried out as well, for example by conducting either a financial merger or a restructuring finance. Therefore, bankruptcy costs could be well-avoided.

\subsection{Bankruptcy Method}

The use of choosen bankruptcy methods in this study will be applied in predicting the certain occurrence of bankruptcy in a company that indicates in experiencing financial distress, before then it is most slightly found to be bankrupt. The four bankruptcy methods used in this study are then presented, as follows:

\section{a) Altman $Z$ - score Method}

This analysis was first introduced by Altman. Altman, in his original study indicated financial ratios that brought a model that could accurately predict the possibility of financial distress potential of a manufacturing company. Thus, Altman Z- score method discriminant equation is explained, as follows:

$$
Z-\text { score }=1,2 \mathrm{X} 1+1,4 \mathrm{X} 2+3,3 \mathrm{X} 3+0,6 \mathrm{X} 4+1,0 \mathrm{X} 5
$$


$\mathrm{X} 1=$ Working Capital/Total Asset

X2 $=$ Retairned Earnings/Total Asset

$\mathrm{X} 3$ = Earning Before Interest and Taxes/Total Asset

X4 = Market Value of Equity/Book Value of Total Debt

X5 $=$ Sales/Total Asset

The classifications of predicting the company whether it could be categorized healthy or bankrupt based on the value of the Altman $\mathrm{Z}$ - score method, are namely:

1. $\quad Z$ value $<1.81$, proving a bankrupt company.

2. Value $1.81<\mathrm{Z}<2.29$, indicating the gray area (couldn't be clearly determined whether the company is healthy safe or bankrupt).

3. Nilai $Z>2,99$ proving a healthy safety/not having bankrupt risk.

\section{b) Springate Score Method}

According to Peter and Yoseph (2011), in Aben, et al. (2015: 3), this model was developed in 1978 by Gordon L.V. Springate. Gordon L.V. Springate (1978) conducted a study to find a model that could be used in predicting the potentials as the indication of getting bankruptcy. The four ratios are formulated as follows:

$$
\mathrm{S}-\text { score }=1,03 \mathrm{X} 1+3,07 \mathrm{X} 2+0,66 \mathrm{X} 3+0,4 \mathrm{X} 4
$$

$\mathrm{X} 1=$ Working Capital/Total Asset

X2 $=$ Net Profit Before Interest and Taxes/Total Asset

X3 $=$ Net Profit Before Taxes/Current Liability

$\mathrm{X} 4=$ Sales/Total Asset

The classifications of predicting the company whether it could be categorized healthy or bankrupt based on the value of S - score Springate method, are namely:

1. Score $S>0,862$ determined as a company that has no potential to go bankrupt.

2. Score $\mathrm{S}<0,862$ is potentially classified as an unhealthy and bankrupt company.

\section{c) Zmijewski X - score Method}

According to Prihantini and Sari (2013: 423), the prediction method suggested by Zmijewski in 1983 was a 20-year research. This method revealed the following formula:

$$
X=-4,3-4,5 \times 1+5,7 X 2-0,004 X 3
$$

$$
\begin{aligned}
& \mathrm{X} 1=R O A \\
& \mathrm{X} 2=\text { Leverage (Debt Ratio) } \\
& \mathrm{X} 3=\text { Liquidity (Current Ratio) }
\end{aligned}
$$

The classifications of predicting the company whether it could be categorized healthy or bankrupt based on the value of $\mathrm{X}$ - score Zmijewski method, are namely:

a) If the score is $>0$ then, the company tends to potentially predict the experience of getting bankruptcy. 
b) If the score is $<0$ then, the company tends potentially not experiencing of getting bankruptcy.

\section{d) Grover G - score Method}

The Grover method is a method introduced by Jeffrey S. Gover by doing, designing and reevaluating from the Altman Z -score method. Jeffrey S. Grover applied a sample according to the Altman Z-score method in 1968 by adding thirteen new financial ratios. (Prihantini and Sari, 2013: 420). Jeffrey S. Grover presented the following functions:

$$
\mathrm{G}-\mathrm{Score}=1,650 \mathrm{X} 1+3,404 \mathrm{X} 2+0,016 \mathrm{ROA}+0,057
$$

$\mathrm{X} 1=$ Working Capital/Total Assets

$\mathrm{X} 2=$ Earning Before Interest and Taxes/Total Assets

$\mathrm{ROA}=$ Net Income/ Total Assets

The classifications of predicting the company whether it could be categorized healthy or bankrupt based on the value of $\mathrm{G}$ - score Grove method, are namely:

a) Score $G \leq-0,02$ the company tends to potentially predict the experience of getting bankruptcy.

b) Score $\mathrm{G} \geq 0,01$ the company tends to potentially not experiencing of getting bankruptcy.

\subsection{Financial Distress}

According to Hanafi Halim (2014: 261) there are several indicators that can be suggested as the predictions of bankruptcy potentials. One classified source is cash flow for nowadays or the near future. Second classified source is the company's strategy. This strategy analysis focuses on several main components, which are: (1) the competition faced by the company, (2) the relative cost structure to its competitors, (3) the quality of management, (4) the ability of controlling costs management, and others. Third source is the company's financial reports. The financial reports may be applied to predict financial difficulties. One last source is the external information. In developed financial markets, rating agencies, their information can be suggested to predict financial distress.

Moreover, the company that performs financial distress is experiencing the instability of negative net incomes for three years. This kind of caution allows management companies to take the safety systems and preventive measures adjusted if financial distress in the entity occurs. According to Fahmi (2011), for the problem of financial distress, in general studies there are four classifications, namely:

a) Financial distress category a; this category is extremely severe and devastating. This category allows companies justified to be in a bankrupt situation.

b) Financial distress category b; this category belongs to slightly high and is considered hazardous. In this position the company must think of finding more realistic solutions supposed to protect particulary its own various assets such as; the sources of assets which considerately could be sold or maintained.

c) Financial Distress category c; this category is categorized into moderate. This category is appropriately for the company that technically is still capable to protect itself with additional funding from internal or external sources.

d) Financial distress category d; obviously this category is in low level. The company is 
normally considered only in experiencing temporary financial fluctuations affected by various external and internal conditions, including the birth or the implementation of inappropriate decisions. With regards to the short term category, this condition can be quickly overcome.

According to Halim (2012), the affecting factors in the occurrence of financial distress are, as follows:

a) Neoclassical Model, Financial distress will occur when the allocation of resources seems not well- appropriate. Estimating difficulties is performed with the use of data and income reports.

b) Financial Model, Financial distress is likely to be characterized by the incorrect financial structure and may cause the liquidation restrictions.

c) Corporate Governance Models, When a company has the proper asset composition and good financial structure, but it is managed poorly, this warning model is enough to be useful as initial information in order to anticipate the occurrence of financial distress.

\section{Methodology}

This research is a escriptive study which aims to describe the existing phenomena (Sukmadinata, 2006: 72). The steps conducting for analyzing the data are, as follows:

\subsection{Calculating Financial Ratio}

Calculating financial ratio towards all data applied the bankruptcy methods within the components calculation, namely; Altman, Springate, Zmijewski and Grover. The calculation of financial ratios is the initial stage of determining the score of each bankruptcy method. Financial ratios used in the method of Altman, Springate, Zmijewski and Grover, includes: (1) Working Capital to Total Asset (WCTA); (2) Retained Earnings to Total Asset (RE_TA); (3) Earnings Before Interest and Taxes to Total Asset (EBIT_TA); (4) Market Value of Equity to Book Value of Total Debt (MVE_BVT); (5) Sales to Total Asset (SA_TA); (6) Return On Asset (ROA); (7) Earnings Before Taxes to Current Liability (EBT CL); (8) Debt Ratio (DR); (9) Current Ratio (CR).

\subsection{Calculating Bankruptcy Methods}

The methods are applied to examine whether the company proceed bankrupt or not in the near future. The calculation of bankruptcy is by inserting the pre-calculated financial ratios into the calculation in each method. The company's bankruptcy methods that are used in this study, as follows: (1) Altman; (2) Springate; (3) Zmijewski; (4) Grover.

\subsection{Making a Comparison Table of Bankruptcy Prediction Results}

The prediction result that has been obtained should be calculated, and then compared to bankruptcy prediction. The number of results is listed in the table according to the obtained results. There are 3 criteria resulted from the prediction, namely; bankrupt, not bankrupt, gray area. 


\section{Result and Discussion}

\subsection{Financial Ratio Calculation Results}

Table 1. The results of Calculation of Financial Ratio at PT. Semen Baturaja Tbk. and PT. Semen Indonesia Tbk. during the Period Year of $2012-2018$

\begin{tabular}{|c|c|c|c|c|c|c|c|c|c|}
\hline \multirow{2}{*}{} & \multicolumn{7}{|c|}{ PT. Semen Baturaja, Tbk. } \\
\cline { 2 - 11 } & WCTA & CR & DR & EBIT_TA & ROA & RE_TA & EBIT_CL & SA TA & MVE_BVT \\
\hline 2012 & $41 \%$ & $389 \%$ & $20 \%$ & $34 \%$ & $25 \%$ & $30 \%$ & $230 \%$ & $91 \%$ & $179 \%$ \\
\hline 2013 & $70 \%$ & $1087 \%$ & $9 \%$ & $14 \%$ & $12 \%$ & $12 \%$ & $206 \%$ & $43 \%$ & $1328 \%$ \\
\hline 2014 & $73 \%$ & $1299 \%$ & $8 \%$ & $11 \%$ & $11 \%$ & $8 \%$ & $225 \%$ & $41 \%$ & $1527 \%$ \\
\hline 2015 & $51 \%$ & $757 \%$ & $9 \%$ & $12 \%$ & $11 \%$ & $9 \%$ & $173 \%$ & $44 \%$ & $896 \%$ \\
\hline 2016 & $12 \%$ & $286 \%$ & $28 \%$ & $9 \%$ & $6 \%$ & $7 \%$ & $119 \%$ & $34 \%$ & $219 \%$ \\
\hline 2017 & $8 \%$ & $167 \%$ & $32 \%$ & $6 \%$ & $3 \%$ & $3 \%$ & $31 \%$ & $30 \%$ & $2289 \%$ \\
\hline 2018 & $13 \%$ & $213 \%$ & $37 \%$ & $7 \%$ & $1 \%$ & $4 \%$ & $22 \%$ & $36 \%$ & $841 \%$ \\
\hline \hline & \multicolumn{7}{|c|}{ PT. Semen Indonesia, Tbk. } \\
\cline { 2 - 11 } & WCTA & CR & DR & EBIT_TA & ROA & RE_TA & EBIT_CL & SA_TA & MVE_BVT \\
\hline 2012 & $12 \%$ & $170 \%$ & $31 \%$ & $25 \%$ & $18 \%$ & $23 \%$ & $130 \%$ & $13 \%$ & $1050 \%$ \\
\hline 2013 & $15 \%$ & $188 \%$ & $29 \%$ & $26 \%$ & $17 \%$ & $22 \%$ & $130 \%$ & $14 \%$ & $937 \%$ \\
\hline 2014 & $18 \%$ & $20 \%$ & $27 \%$ & $24 \%$ & $16 \%$ & $20 \%$ & $134 \%$ & $14 \%$ & $1009 \%$ \\
\hline 2015 & $10 \%$ & $159 \%$ & $28 \%$ & $19 \%$ & $12 \%$ & $15 \%$ & $88 \%$ & $13 \%$ & $542 \%$ \\
\hline 2016 & $5 \%$ & $127 \%$ & $30 \%$ & $15 \%$ & $10 \%$ & $11 \%$ & $62 \%$ & $10 \%$ & $427 \%$ \\
\hline 2017 & $10 \%$ & $156 \%$ & $38 \%$ & $9 \%$ & $3 \%$ & $5 \%$ & $25 \%$ & $49 \%$ & $339 \%$ \\
\hline 2018 & $15 \%$ & $195 \%$ & $36 \%$ & $12 \%$ & $6 \%$ & $9 \%$ & $50 \%$ & $50 \%$ & $289 \%$ \\
\hline
\end{tabular}

When compared to the liquidity ratio at PT. Semen Baturaja Tbk. with the liquidity ratio at PT. Semen Indonesia Tbk. showed that the number of liquidity ratio which is namely WCTA of PT. Semen Baturaja Tbk is indicated much bigger than PT. Semen Indonesia. This showed that the ability to pay off the short-term debts of PT. Semen Baturaja Tbk. is much greater than the ability to pay off the short-term debts by PT. Semen Indonesia Tbk. Furthermore, the CR at PT. Semen Baturaja Tbk is also significantly greater than PT. Semen Indonesia Tbk. That is because the number of current assets owned by PT. Semen Baturaja Tbk is much bigger than PT. Semen Indonesia Tbk.

For the solvency ratio using the DR calculation, PT. Semen Indonesia Tbk is higher than PT. Semen Baturaja Tbk. This means the funding using debts at PT. Semen Indonesia Tbk is much more than the funding with debts at PT. Semen Baturaja Tbk. Based on the calculation of the debt ratio between PT. Semen Baturaja Tbk. and PT. Semen Indonesia Tbk. showed that PT. Semen Indonesia Tbk is likely to hold funding with debts which indicated, by contrast, greater than the debts ratio at PT. Semen Baturaja Tbk.

Further, the index profitability ratio at PT. Semen Indonesia Tbk is higher than the ratio in PT. Semen Baturaja Tbk. In other words, PT. Semen Indonesia Tbk. is certainly better able to utilize its assets to generate profits from business operations. From 2012 - 2018 ROA at PT. Semen Baturaja Tbk and PT. Semen Indonesia Tbk. indicated dropped, but, ROA at PT. Semen Indonesia is higher than ROA at PT. Semen Baturaja Tbk. This could be meant that the profit generated by PT. Semen Indonesia Tbk. is greater than the profit generated by PT. Semen Baturaja Tbk. from the period year of 2012 - 2018. RETA at PT. Semen Indonesia Tbk. is higher than the RETA at PT. Semen Baturaja Tbk. which means that PT. Semen Indonesia Tbk. has high profits to fund its assets and pay off the dividends. EBTCL is a ratio that used for analyzing profits. The calculation results showed that the ratio value at PT. Semen Baturaja Tbk. is greater 
than the ratio at PT. Semen Indonesia Tbk. which can be said that the gross profit obtained by PT. Semen Baturaja Tbk. is greater than the profit earned by PT. Semen Indonesia Tbk. from the period of year 2012 - 2018. Accordingly, the basis of calculation used to compare profitability at PT. Semen Baturaja Tbk. and PT. Semen Indonesia Tbk., includes; (1) gross profit, (2) net profit, (3) retained profit and, (4) profit before tax. The analysis results obtained are; PT. Semen Indonesia Tbk. has a higher profit compared to PT. Semen Baturaja Tbk. so that it is much better able to utilize its assets to get optimum profits from the results of its operational performances and it has the ability to fund the company assets and pay off dividends.

This activity ratio is a ratio to determine the increase and decrease in sales. From the calculation results obtained indicated that sales at PT. Semen Baturaja Tbk. are much greater than the sales at PT. Semen Indonesia Tbk. If on the average, sales at PT. Semen Baturaja Tbk. over the period year of 2012 - 2018 clarified $45 \%$ and PT. Semen Indonesia Tbk by $23 \%$. Thus, the sales from 2012 to 2018 were much more significant at PT. Semen Baturaja Tbk. compared to PT. Semen Indonesia Tbk. Although the sales of PT Semen Baturaja, Tbk. are greater than PT Semen Indonesia, Tbk. but, the gained profits of PT. Semen Baturaja, Tbk. is less than PT. Semen Indonesia Tbk. It could be meant that the sales costs of PT. Semen Baturaja, Tbk. are greater than PT. Semen Indonesia, Tbk. Thus, the financial costs spent by PT Semen Indonesia, Tbk. were more efficient in managing operational costs compared to PT. Semen Baturaja, Tbk.

The results obtained from the MVEBVT calculation showed that the index market ratio at PT. Semen Baturaja Tbk. was higher than the index market ratio at PT. Semen Indonesia Tbk. The calculation of this market ratio is based on the number of shares received by the company and multiplied by the price of current shares, then divided by total of liabilities.

\subsection{The Calculation Results using the Bankruptcy Methods}

By using the Altman method, PT. Semen Baturaja Tbk. showed a low score in 2016, so that its status went bankrupt which the affecting factor was the shares dropped significantly in 2016. In contrast, PT. Semen Indonesia has no bankruptcy status. The calculation results from the Springate method showed that in 2017 and 2018, PT. Semen Baturaja Tbk went bankrupt due to a decrease in the ratio of capital and profit before tax which was gained by the cement company. Whereas, PT. Semen Indonesia Tbk was potentially to be bankrupt found in 2017 where there was a decrease in the amount of gross profit gained by the company. Based on the calculations results using the Zmijewski method, the two companies were not proved having bankrupt status from the period year 2012 to 2018 . Although they were not indicated being bankrupt status, during the 7-year period, PT. Semen Baturaja Tbk showed a continuous decline in ROA for 7 years. Bankruptcy calculations using these methods overall showed the results that both PT. Semen Baturaja Tbk and PT. Semen Indonesia Tbk certainly had no bankrupt potensials. As a conclusion, for 7 years, from the period year of 2012 to 2018 , the two companies were pleasantly considered not showing bankruptcy.

Table 2. The Calculation Results using the Bankruptcy Methods at PT. Semen Baturaja Tbk. and PT. Semen Indonesia Tbk. during the Period Year of 2012 - 2018 


\begin{tabular}{|c|r|c|r|r|r|r|r|c|}
\hline \multirow{2}{*}{} & \multicolumn{9}{|c|}{ PT. Semen Baturaja, Tbk. } \\
\cline { 2 - 10 } & \multicolumn{2}{|c|}{ Altman } & \multicolumn{2}{c|}{ Springate } & \multicolumn{2}{c|}{ Zmijewski } & \multicolumn{2}{c|}{ Grover } \\
\cline { 2 - 10 } & Z- Score & Status & S-Score & Status & X-Score & Status & G - Score & Status \\
\hline 2012 & 3,11 & TB & 3,35 & TB & $-3,13$ & TB & 1,89 & TB \\
\hline 2013 & 9,44 & TB & 2,68 & TB & $-3,20$ & TB & 1,69 & TB \\
\hline 2014 & 10,51 & TB & 2,74 & TB & $-3,30$ & TB & 1,63 & TB \\
\hline 2015 & 6,51 & TB & 2,21 & TB & $-3,26$ & TB & 1,31 & TB \\
\hline 2016 & 1,85 & B & 1,32 & TB & $-2,42$ & TB & 0,56 & TB \\
\hline 2017 & 14,07 & TB & 0,59 & B & $-2,33$ & TB & 0,39 & TB \\
\hline 2018 & 5,49 & TB & 0,64 & B & $-2,14$ & TB & 0,51 & TB \\
\hline Average & $\mathbf{7 , 2 8}$ & TB & $\mathbf{1 , 9 3}$ & TB & $-2,83$ & TB & $\mathbf{1 , 1 4}$ & TB \\
\hline
\end{tabular}

\begin{tabular}{|c|c|c|r|r|r|r|r|c|}
\hline \multirow{2}{*}{} & \multicolumn{9}{|c|}{ PT. Semen Indonesia, Tbk. } \\
\cline { 2 - 10 } & \multicolumn{2}{|c|}{ Altman } & \multicolumn{2}{c|}{ Springate } & \multicolumn{2}{|c|}{ Zmijewski } & \multicolumn{2}{c|}{ Grover } \\
\cline { 2 - 10 } & Z- Score & Status & S-Score & Status & X-Score & Status & G - Score & Status \\
\hline 2012 & 7,59 & TB & 1,80 & TB & $-1,71$ & TB & 1,11 & TB \\
\hline 2013 & 6,97 & TB & 1,87 & TB & $-1,87$ & TB & 1,19 & TB \\
\hline 2014 & 7,34 & TB & 1,86 & TB & $-2,03$ & TB & 1,17 & TB \\
\hline 2015 & 4,21 & TB & 1,32 & TB & $-2,16$ & TB & 0,87 & TB \\
\hline 2016 & 3,27 & TB & 0,96 & TB & $-2,12$ & TB & 0,65 & TB \\
\hline 2017 & 2,52 & TB & 0,74 & B & $-1,99$ & TB & 0,52 & TB \\
\hline 2018 & 2,44 & TB & 1,05 & TB & $-1,97$ & TB & 0,71 & TB \\
\hline Average & 4,91 & TB & 1,37 & TB & $-1,98$ & TB & $\mathbf{0 , 8 9}$ & TB \\
\hline
\end{tabular}

$\mathrm{TB}=($ Not Bankrupt $) ; \mathrm{B}=($ Bankrupt $)$

\subsection{Comparative Results of Bankruptcy Calculation}

Table 4. The Results of Bankruptcy Predictions at PT. Semen Baturaja Tbk. and PT. Semen Indonesia Tbk. during the Period Year of 2012 - 2018

\begin{tabular}{ccccc}
\hline \multirow{2}{*}{ Prediction Methods } & \multicolumn{3}{c}{ Comparative Results } & \\
\cline { 2 - 4 } & Bankrupt & Gray Area & Not Bankrupt & Total \\
\hline Altman & 1 & - & 6 & 7 \\
Springate & 2 & - & 5 & 7 \\
Zmijewski & - & - & 7 & 7 \\
Grover & - & - & 7 & 7 \\
\hline
\end{tabular}

Comparative Results

\begin{tabular}{ccccc} 
Prediction Methods & \multicolumn{3}{c}{ Total } \\
\cline { 2 - 5 } & Bankrupt & $\begin{array}{c}\text { Gray } \\
\text { Area }\end{array}$ & $\begin{array}{c}\text { Not } \\
\text { Bankrupt }\end{array}$ & \\
\hline Altman & - & - & 7 & 7 \\
Springate & 1 & - & 6 & 7 \\
Zmijewski & - & - & 7 & 7 \\
Grover & - & - & 7 & 7 \\
\hline
\end{tabular}

Source: Processed Data

Using the obvious results from the average score in each bankruptcy method then matching 
with the cut-off value of each bankruptcy method represented that PT. Semen Baturaja Tbk. in a condition not experiencing financial distress. At first, the average score on the Altman method was 7.283 and the $Z$ value cut-off- if $Z$ score $>1.81$ was considered in the healthy category and safe from financial problem. The Springate's S score had average score of 1.932 and the S value of the cut - off S - if S score $>0,862$ categorized into a good healthy position. Then, the average score on Zmijewski method was 2.827 and the value of the cut - off Zmijewski - if X score $<0$, which performed that the company was in the healthy condition. The last, the results of calculations using the Grover method had an average score of 1.141 and a Grover cut- off value if the G- Score $\geq 0.01$ meaning that the company was in the healthy category. Although the company's condition for 7 years did not show having the bankrupt potentials, but, the index ratio of calculation results in each period showed significantly a decrease.

Respectively, the results of PT. Semen Indonesia Tbk. indicated that the company's condition did not perform financial distress which the average score at 4.905 Altman's method and the value of the cut - off $\mathrm{Z}-$ if $\mathrm{Z}$ score $>1.81$, belonged the healthy category. Next, the average score using Springate's method was 1,371 and the value of the cut - off S - if S score $>0,862$ wass in a healthy company category. Then, the average score using the Zmijewski method was $-1,980$ and the cut - off value of the Zmijewski method if $\mathrm{X}$ score $<0$ which dealt the company was in the healthy category. While the results of calculations using the Grover method had the average score of 0.891 and a Grover cut-off value if the G - Score $\geq 0.01$ meaning the company was in the healthy category. Although the company's condition for 7 years represented not having bankruptcy potentials, but the index ratio of calculation results from each period showed a decrease, except in the calculation using the Springate method, which indicated that the calculation results have increased in 2018.

Regarding with the composition of assets and a good financial structure, PT. Semen Baturaja Tbk. and PT. Semen Indonesia Tbk. are likely to be managed in the poor performance, which apparently will continue to experience decline in sales and be threatened with the emerge of financial distress. This model is very useful as the initial information to anticipate the upcoming of financial distress.

\section{Conclusion And Suggestion}

The findings of this research can be concluded that there are differences in the results of bankruptcy prediction using the Altman Z-score, Springate, Zmijewski and Grover methods which are described in the following conclusion:

a) The Financial distress analysis by using the Altman Z-score, Springate, Zmijewski and Grover methods at PT. Semen Baturaja Tbk. and PT. Semen Indonesia Tbk. for the period year of 2012-2018 indicated that in 2016 PT. Semen Baturaja Tbk. was in an unhealthy condition based on the Altman method. While in 2017 and 2018 PT. Semen Baturaja Tbk. showed in getting of the unhealthy condition based on the Springate method. Then, the analysis result at PT. Semen Indonesia showed that the financial warning had the warning system in 2017 which this company was categorized into less healthy based on the Springate method.

b) The comparative results of the Altman Z- Score, Springate, Zmijewski and Grover methods in measuring financial distress showed that PT. Semen Baturaja Tbk. and PT. Semen Indonesia Tbk. which on average, have been investigated in this research were both not performing of financial distress considered by the development of the ratio 
from 2012 to 2018 . However, the results obtained in this research also showed a decline in financial ratio from year to year starting from 2012-2018.

Based on the obvious results of this research that have been in the previous description, the researchers provide suggestions, as follows:

a) PT. Semen Baturaja Tbk and PT. Semen Indonesia Tb. are expected to increase the sales capacity and to efficiently carry out the production activities in order to improve the company profitability.

b) In the future studies, it will be more necessary to analyze the causes of financial distress in depth by distributing questionnaires to both companies

\section{References}

[1] Aileen, F. (2001). Understanding Financial Statement. New Jersey: Sixth Edition.

[2] Ashari, D. (2005). Pedoman Praktis Memahami Laporan Keuangan. Jakarta: Salemba Empat.

[3] Copeland, F. J. (1997). Managerial Finance. Diterjemahkan Oleh Jaka Wansan dan Kribhandoko.

[4] Fahmi, I. (2011). Analisis Laporan Keuangan. Bandung: Alfabeta.

[5] Halim, M. H. (2012). Analisis Laporan Keuangan. Yogyakarta: Unit Penerbit dan Percetakan Sekolah Tinggi Ilmu Manajemen YKPN.

[6] Halim, M. M. (2009). Analisis Laporan Keuangan. Yogyakarta: Edisi Keempat Cetakan Pertama CARS.

[7] Hanafi, M. (2010). Manajemen Keuangan. Yogyakarta: BPFE Yogyakarta Edisi 1.

[8] Kasmir S E, M. (2016). Analisis Laporan Keuangan. Jakarta: Rajawali Pers.

[9] Kasmir, D. (2008). Analisis Laporan Keuangan.

[10] Depok: Cetakan Ke - 9 Rajawali Pers. McKinsey Global Institute. (2012a). Manufacturing the Future: The Next Era of Global Growth and Innovation. McKinsey \& Company. McKinsey Global Institute. (2012b). The Archipelago Economy: Unleashing Indonesia's Potential. McKinsey \& Company. Munawir. (2010). Analisis Laporan Keuangan. Yogyakarta: Liberty Edisi Keempat.

[11] Prihadi, T. (2010). Analisis Laporan Keuangan. Jakarta: PPM:Manajemen. Sukmadinata, 2006. Metode Penelitian Kualitatif. Bandung: Graha Aksara Journals Aben, D. A. (2015).

[12] Analisis Metode Springate (S - score). Jurnal Administrasi Bisnis, Vol.21 No. 1:3. Karina, Sevira Dita. (2014). Prediksi Kebangkrutan pada Perusahaan Media yang Terdaftar di Bursa Efek Indonesia. Politeknik Negeri Sriwijaya. Palembang. Kurniasih, M. A. (2000). Analisis Tingkat Kesehatan Perusahaan Untuk Memprediksi Potensi Kebangkrutan Dengan Pendekatan Altman . Jurnal Akuntansi dan Auditing, Vol.4 No.2 : 131 - 151. Nainggolan, H. (2017). Analisis Risiko Keuangan Dengan Model Altman Z - score. Jurnal Ilmiah Akuntansi dan Keuangan, Vol.6, No.1: 96.

[13] Ngatijah, Siti. (2016) PERBANDINGAN MODEL PREDIKSI KEBANGKRUTAN (Altman, Springate, Zmijewski, Grover)A. FAKULTAS EKONOMI DAN BISNIS, Universitas Lampung.

[14] Priambodo, Dimas. (2017) Analisis Perbandingan Model Altman, Springate, Grover, Dan Zmijewski Dalam Memprediksi Financial Distress (Studi Empiris Pada Perusahaan Sektor Pertambangan Yang Terdaftar Di Bursa Efek Indonesia Periode 2012- 2015), Universitas Negeri Yogyakarta Prihantini, N. M. (2013). Prediksi Kebangkrutan Dengan Model Grover, Altman. E Journal Akuntansi Universitas Udayana, Vol. 52, 420 - 423.

[15] Purnajaya dan Merkusiwati. (2014). Analisis Komparasi Potensi Kebangkrutan dengan Metode Z-Score Altman, Springate, dan Zmijewski pada Industri. Kosmetik yang Terdaftar di Bursa Efek Indonesia.

[16] Nurcahyanti, W. (2015). Studi KomparatifModel Altman Z - score, Springate dan Zmijewski dalam Mengindikasi Kebangkrutan Perusahaan yang Terdaftar di BEI. Artkel Ilmiah.

[17] E-Jurnal Akuntansi, Vol. 7, No. $1: 48$ - 63. Universitas Udayana Suherman, H. B. (2019).

[18] ANALISIS KINERJA KEUANGAN PERUSAHAAN MANUFAKTUR (Sebuah Studi Empiris 
Pada Perusahaan Manufaktur Industri Logam Go Public di BEI) Periode 2012-2016. JURNAL

ILMIAH FEASIBLE, Vol. 1, No. 1 : 39 - 52 